\title{
PELAJARAN DARI KONFLIK ANTARA KOMUNITAS SEDULUR SIKEP DAN INDUSTRI SEMEN DI JAWA TENGAH
}

\author{
Joeni Arianto Kurniawan* \\ Departemen Dasar Ilmu Hukum, Fakultas Hukum Universitas Airlangga \\ Jalan Dharmawangsa Dalam Selatan, Airlangga, Gubeng, Kota Surabaya, Jawa Timur 60286
}

\begin{abstract}
Depicting the development of the adat law teaching in current days results in a quite unhappy situation, where there is a huge gap between what taught in the classrooms of the law schools in Indonesia and what happens in the reality. The cause of such situation is because there has not been any contemporary comprehensive research on adat laws of Indonesia today in one hand, and also the legal politics implemented by the state which leads the legal system to be more and more state-centered on the other hand. However, though there is an urgent need to overhaul the subject of adat law, in some areas, such as in tenurial matters, some principles of adat law still play a strong role for the interest of the adat communities (masyarakat adat) to defend their tenurial rights. One of the examples of this situation is what I found during my research on a traditional community called Sedulur Sikep in Pati, Central Java, who actively resists the cement industry planned to be established in the area of Kendeng mountain. There are some traditional principles that lie behind such resistance, in which one of them is that this community perceives the Kendeng mountain as "their mother". This principle is actually the principle of adat land law. Thus, if such principles of adat law are understood and regarded well by the state officials as well as by the private actors, land conflict and land grabbing which are frequently suffered by adat communities in Indonesia should be able to be prevented. In order to be so, there must be a significant paradigmatic change both in the realm of legal policy and also in the realm of legal education.
\end{abstract}

Keywords: adat law studies, recognition, protection, rights of the indigenous people, Sedulur Sikep community.

\section{Intisari}

Perkembangan studi hukum adat hari ini berada pada situasi yang tidak menggembirakan, sebab telah ada jurang perbedaan yang lebar antara apa yang diajarkan di kelas di fakultas-fakultas hukum di Indonesia dengan apa yang terjadi di lapangan. Penyebab terjadinya hal ini adalah karena ketiadaan riset-riset kontemporer yang komprehensif dalam bidang hukum adat di Indonesia hari ini di satu sisi, serta adanya politik hukum yang diterapkan negara yang menjadikan sistem hukum yang ada kian bersifat sentralistis pada sisi yang lain. Namun demikian, terlepas dari adanya kebutuhan untuk diadakannya perombakan besar-besaran atas mata kuliah hukum adat, dalam beberapa hal, seperti dalam isu hak tenurial, beberapa prinsip hukum adat masih memegang peranan penting bagi kepentingan masyarakat adat dalam upaya mempertahankan hak-hak tenurial mereka. Salah satu contohnya adalah apa yang telah ditemukan dalam penelitian penulis terhadap komunitas tradisional "Sedulur Sikep" di Pati, Jawa Tengah, yang secara aktif melakukan perlawanan terhadap pendirian industri semen di Pegunungan Kendeng. Hasil penelitian saya menemukan adanya prinsip-prinsip tradisional yang berada di balik aktivitas perlawanan tersebut, salah satunya adalah keyakinan komunitas ini bahwa Pegunungan Kendeng adalah layaknya "ibu" bagi mereka. Prinsip ini sesungguhnya adalah salah satu prinsip dasar hukum adat tentang tanah. Oleh karena itu, jika prinsip sebagaimana demikian dipahami dan dihormati secara sungguh-sungguh oleh semua aktor yang terlibat, baik itu aparat pemerintah maupun para pengusaha, konflik tanah dan perampasan lahan yang sering dialami oleh masyarakat adat di Indonesia seharusnya bisa dicegah. Untuk itu, maka harus ada perubahan paradigma yang signifikan baik di sektor kebijakan hukum dan juga di sektor pendidikan hukum yang ada selama ini.

Kata Kunci: kajian hukum adat, pengakuan, perlindungan, hak masyarakat adat, komunitas Sedulur Sikep.

* Alamat korespondensi: joeni@fh.unair.ac.id 


\section{Pokok Muatan}

A. Pendahuluan 507

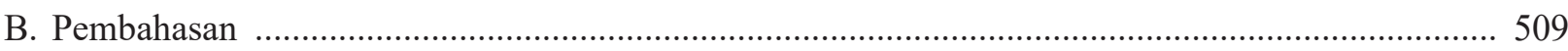

1. Sejarah Pendidikan Hukum dan Kebijakan Hukum di Indonesia: Jurang Epistemik dalam Kajian Hukum Adat

2. "Bumi sebagai Ibu": Prinsip Dasar Hukum Adat tentang Tanah dan Landasan Pergerakan Masyarakat Adat dalam Memperjuangkan Hak Tenurial. Sebuah Contoh dari Komunitas Sedulur Sikep

C. Penutup

\section{A. Pendahuluan}

26 Maret 2013 adalah sebuah hari bersejarah bagi masyarakat adat di Indonesia. ${ }^{1}$ Pada hari tersebut, Mahkamah Konstitusi Republik Indonesia (MKRI) mengeluarkan sebuah putusan yang bisa dimaknai sebagai produk hukum paling penting bagi masyarakat adat dalam sejarah kontemporer Indonesia.

Putusan tersebut adalah putusan nomor 35/ PUU-X/2012, yang kemudian dikenal dengan istilah "Putusan MK35". Isi putusan ini memberikan kembali hak tenurial masyarakat adat atas hutan setelah sebelumnya diabaikan begitu saja oleh aturan hukum di dalam Undang-Undang Nomor 41 Tahun 1999 tentang Kehutanan. Melalui Putusan MK35 ini, kini masyarakat adat memiliki hutan yang khusus secara eksklusif menjadi hak mereka, yang dinamakan sebagai "hutan adat".

Putusan MK35 ini kemudian diikuti oleh dikeluarkannya beberapa Keputusan Presiden (Kepres) pada tanggal 30 Desember 2016 yang isinya menetapkan sembilan hutan adat kepada sembilan komunitas masyarakat adat di Indonesia. ${ }^{2}$ Meskipun masih jauh dari ekspektasi, pemerintah sendiri telah menetapkan target sebesar 12,7 juta hektar hutan adat untuk diberikan kepada komunitas-komunitas masyarakat adat di Indonesia. Perkembangan ini jelas merupakan tren positif bagi pengakuan dan perlindungan hak-hak masyarakat adat. $^{3}$

Tren positif tersebut niscaya akan mendorong masyarakat adat di Indonesia untuk lebih persisten dalam memperjuangkan pengakuan dan perlindungan hak-hak tenurial mereka. Oleh karenanya pergerakan dan perjuangan masyarakat adat akan menjadi lebih dinamis. Secara logis, dinamika perjuangan masyarakat adat yang menjadi lebih berkembang ini seharusnya juga mendorong dinamika diskursus tentang hukum adat, mengingat kehidupan masyarakat adat jelas tidak bisa dipisahkan dari eksistensi hukum adat. ${ }^{4}$ Hal tersebut juga diakui oleh MK di dalam isi putusannya

1 Terdapat dua istilah yang biasa disematkan pada eksistensi masyarakat adat di Indonesia, yakni: "masyarakat adat" dan "masyarakat hukum adat." Kedua istilah ini memiliki sedikit perbedaan konseptual. Namun, dalam artikel ini saya menggabungkannya menjadi satu istilah yang sama, yakni "masyarakat adat." Alasan saya dalam melakukan hal ini antara lain adalah: Pertama, sebagaimana dijelaskan oleh Rikardo Simarmata dalam bukunya berjudul "Pengakuan Hukum terhadap Masyarakat Adat di Indonesia" (2006, p. 26), kedua istilah tersebut memiliki esensi dasar yang sama dan oleh karenanya dalam ukuran tertentu dapat digunakan untuk merujuk hal yang sama, di samping bahwa terminologi "masyarakat adat" memiliki cakupan makna yang lebih luas yang tidak hanya terbatas pada konteks hukum (sebagaimana yang menjadi cakupan dari terminologi "masyarakat hukum adat"). Kedua, istilah "masyarakat adat" sejalan dengan istilah yang digunakan di dalam diskursus internasional, yakni "indigenous people". Ketiga, terminologi "masyarakat adat" juga sesuai dengan aspirasi dari masyarakat adat sendiri, khususnya yang tergabung dalam "Aliansi Masyarakat Adat Nusantara" (AMAN) sebagai organisasi masyarakat adat terbesar di Indonesia..

2. Humas Sekretariat Kabinet Republik Indonesia, "Serahkan 9 Surat Pengakuan Hutan Adat, Presiden Jokowi: Pertahankan Fungsi Konservasi, Jangan Diperjualbelikan", http://setkab.go.id/serahkan-9-surat-pengakuan-hutan-adat-presiden-jokowi-pertahankan-fungsi-konservasijangan-diperjualbelikan/.

3. Ibid.

4. Di dalam mengembangkan konsep tentang hukum adat, Van Vollenhoven, yang kemudian dikenal sebagai "Bapak Studi Hukum Adat Indonesia", mengelaborasi istilah "hukum adat" sebagai adat yang memiliki konsekuensi hukum, yang terbentuk dari gabungan hukum asli rakyat Indonesia, sebagai elemen penyusunnya yang terbesar, ditambah dengan elemen asing yang berasal dari hukum agama. Holleman, J, 1981, Van Vollenhoven on Indonesian Adat Law, Martinus Nijhoff, The Hague, hlm. 5. 
nomor 31/PUU-V/2007, yang menyatakan bahwa eksistensi hukum adat adalah salah satu faktor untuk menentukan eksistensi suatu komunitas masyarakat adat. $^{5}$

Nyatanya perkembangan hukum adat sebagai subyek mata kuliah yang diajarkan di fakultasfakultas hukum di Indonesia adalah tidak demikian. Berdasarkan pengalaman pribadi penulis sebagai dosen pada mata kuliah ini, hukum adat nampaknya telah menjadi suatu mata kuliah yang mati. Hal ini dapat dilihat dari fakta tidak adanya perubahan signifikan atas kurikulum pengajaran hukum adat. Melalui pengumpulan beberapa silabus mata kuliah hukum adat di fakultas-fakultas hukum di Indonesia, kita dengan mudah dapat mengetahui bahwa walaupun ada sedikit variasi di sana-sini, topiktopik yang diberikan dalam mata kuliah hukum adat di fakultas-fakultas hukum pada universitas satu dengan yang lain kurang lebih adalah sama.

Salah satu faktor yang menyebabkan adanya fenomena sebagaimana demikian adalah adanya kekurangan atas referensi-referensi kontemporer. Sebagaimana bisa kita lihat dari silabus-silabus tersebut, yang juga terjadi di fakultas penulis sendiri di Universitas Airlangga Surabaya, mayoritas referensi yang ada yang digunakan sebagai bahan pembelajaran mata kuliah hukum adat masihlah pada "buku-buku klasik". Contohnya seperti karyakarya para sarjana semacam Iman Sudiyat, Surojo Wignjodipuro, Djojodigoeno, dan Supomo. Jika melihat lagi secara lebih teliti, buku-buku sarjana dari generasi yang lebih muda, seperti Iman Sudiyat dan Surojo Wignjodipuro, dalam ukuran tertentu merupakan "daur-ulang" dari karya sarjana-sarjana generasi sebelumnya, seperti Djojodigoeno dan Soepomo. Sedangkan karya dari sarjana generasi yang lebih tua ini merupakan hasil dari "daur-ulang" atas buku-buku yang lebih tua lagi semacam karya dari Ter Haar. Adanya hal tersebut bisa dipahami jika kita memperhitungkan faktor sejarah bahwa sarjana-sarjana hukum adat generasi pertama seperti Djojodigoeno dan Soepomo tidak lain adalah muridmurid dari Ter Haar di Batavia Rechtshoogeschool. ${ }^{6}$

Adanya situasi sebagaimana demikian tentu bukanlah situasi yang menggembirakan, terutama jika kita mengharapkan adanya keterhubungan dan kontribusi timbal balik yang positif antara perkembangan yang ada dalam lingkup akademis (di Indonesia) dengan dinamika pergerakan masyarakat adat yang terjadi di lapangan. Hal inilah kiranya yang membuat pergerakan masyarakat adat dan perjuangan atas hak-hak mereka kurang mendapatkan dukungan dari kalangan akademisi di kampus-kampus di Indonesia yang ahli di bidang hukum adat. Alih-alih mayoritas dukungan yang ada berasal dari organisasi-organisasi masyarakat sipil yang memiliki keahlian tidak hanya dalam pemberian pendampingan hukum, sosial, dan politik bagi masyarakat adat, tetapi juga intensif dalam melakukan penelitian dalam rangka untuk mengumpulkan data-data yang dibutuhkan guna mendukung perjuangan masyarakat adat. ${ }^{7}$ Suatu tugas yang, menurut pandangan penulis selaku akademisi, seharusnya merupakan tanggung jawab dari para sarjana-sarjana ahli hukum adat yang ada di kampus.

Mengapa seharusnya terdapat keterhubungan dan kontribusi timbal balik yang positif antara perkembangan diskursus hukum adat di lingkungan akademik dengan pergerakan masyarakat adat? Merujuk pada hasil penelitian penulis atas komunitas tradisional "Sedulur Sikep" yang ada di Jawa Tengah, di samping adanya kecenderungan terjadinya stagnasi pengajaran hukum adat yang ada di universitas-universitas, penulis masih dapat melihat adanya beberapa prinsip dasar hukum adat tentang tanah dan hak tenurial sebagai bagian dari obyek kajian mata kuliah hukum adat yang diajarkan

5. Putusan Mahkamah Konstitusi Nomor 31/PUU-V/2007 perihal Pengujian Undang-Undang Nomor 31 Tahun 2007 tentang Pembentukan Kota Tual di Propinsi Maluku terhadap Undang-Undang Dasar Negara Republik Indonesia Tahun 1945, 18 Juni 2008, hlm. 155-156.

6. S. Wignjosoebroto, 1994, Dari Hukum Kolonial ke Hukum Nasional, Radja Grafindo Persada, Jakarta.

7. Beberapa contoh dari organisasi masyarakat sipil seperti ini di Indonesia adalah HuMa and Epistema Institute, keduanya berbasis di Jakarta, yang merupakan organisasi masyarakat sipil yang paling menonjol, di samping AMAN, yang banyak bersentuhan dengan pergerakan masyarakat adat di Indonesia dewasa ini. 
di fakultas-fakultas hukum di Indonesia hingga hari ini. Hal tersebut masih dipertahankan dan digunakan oleh komunitas ini sebagai landasan perjuangan mereka dalam mempertahankan tanah mereka melawan rencana pendirian industri semen di Jawa Tengah. Berdasarkan hal itu penulis membayangkan jika diskursus hukum adat lebih dikembangkan lagi oleh fakultas-fakultas hukum yang ada di berbagai universitas di Indonesia. Paling tidak seintensif apa yang telah dilakukan oleh berbagai organisasi masyarakat sipil pendamping masyarakat adat yang ada selama ini. Perjuangan atas pengakuan dan perlindungan hak-hak masyarakat adat akan jauh lebih efektif dan berhasil dari apa yang telah terjadi saat ini.

Oleh karena itu, penulis hendak menunjukkan bagaimana perjuangan hak tenurial masyarakat adat di Indonesia sesungguhnya memiliki keterkaitan yang kuat dengan mata kuliah hukum adat yang diajarkan di fakultas-fakultas hukum di berbagai universitas yang ada, khususnya dalam topik hukum tanah. Hal ini mengambil contoh dari pengalaman penulis dalam meneliti komunitas tradisional Sedulur Sikep di Kabupaten Pati, Propinsi Jawa Tengah. Sebelumnya akan dijelaskan mengapa kajian hukum adat yang ada di kampus-kampus di Indonesia cenderung mengalami stagnasi, yakni dengan membawa kepada konteks historis pendidikan hukum dan politik pengembangan hukum di Indonesia secara umum. Pada bagian akhir, penulis akan menutup artikel ini dengan memberikan beberapa refleksi dan saran tentang bagaimana kajian-kajian hukum adat di universitasuniversitas seharusnya dilakukan overhaul agar kajian hukum adat di kampus bisa sejalan dengan realitas dinamika kehidupan masyarakat adat yang terjadi di Indonesia hari ini.

\section{B. Pembahasan}

\section{Sejarah Pendidikan Hukum dan Kebi- jakan Hukum di Indonesia: Jurang Epis- temik dalam Kajian Hukum Adat}

Sebagaimana diungkapkan secara tepat oleh Frans dan Keebet von Benda-Beckmann, ${ }^{8}$ hukum adat, sebagai sebuah model hukum yang seharusnya masuk ke dalam kategori living law, telah menjadi (kajian) "hukum yang mati" (a dead law) sejak ia pertama kali menjadi subyek mata kuliah yang diajarkan di fakultas hukum di Indonesia. ${ }^{9}$

Adalah Sekolah Tinggi Hukum Batavia (Rechtshoogesschool van Batavia, yang pada periode sebelumnya cukup disebut sebagai Rechtschool van Batavia), sebagai sekolah hukum yang didirikan oleh Pemerintah Kolonial Hindia Belanda dan didesain sebagai tempat untuk mendidik para mahasiswa dari golongan pribumi. Nantinya mereka akan menjadi administrator hukum (hakim, jaksa, dan panitera) di Pengadilan Landraad yang merupakan tempat di mana hukum adat pertama kali diperkenalkan sebagai subyek kajian hukun yang diajarkan yang setara dengan subyek ilmu hukum lainnya yang mayoritas diambil dari kajian ilmu hukum Eropa.

Adanya keterkaitan kuat antara eksistensi Rechtshoogesschool van Batavia dan Pengadilan Landraad inilah, yang merupakan pengadilan yang khusus diperuntukkan guna mengadili perkaraperkara umum di kalangan masyarakat golongan pribumi (pada masa kolonial). Hukum adat sebagai subyek kajian ilmu hukum diajarkan kepada para mahasiswa di Rechtshoogesschool sehingga para calon administrator hukum Landraad nantinya akan memiliki kecakapan untuk menyelesaikan perkara di antara golongan mereka dengan hukum mereka sendiri, yakni hukum adat. ${ }^{10}$

8. F. Benda-Beckmann, "The Social Life of Living law in Indonesia”, In M. Hertogh, 2009, Living Law. Reconsidering Eugen Ehrlich, Hart Publishing, Oxford and Portland Oregon hlm. 187.

9 Makna dari istilah living law di sini merujuk pada konsep sebagaimana diperkenalkan oleh Eugen Ehrlich, yakni hukum yang senyatanya paling banyak berpengaruh atau mendominasi kehidupan suatu masyarakat, walaupun belum terwujud ke dalam sebuah proposisi hukum yang resmi sekalipun, yang bisa didapatkan pada setiap tatanan internal dari setiap asosiasi social. Juga dapat dilihat di M. Hertogh, "From 'Men of Files' to 'Men of the Senses': A Brief Characterisation of Eugen Ehrlich's Sociology of Law”, In M. Hertogh, 2009, Living Law. Reconsidering Eugen Ehrlich, Hart Publishing, Oxford and Portland Oregon, hlm. 3 dan J. Griffits, What is Legal Pluralism, Journal of Legal Pluralism and Unofficial Law, Nomor 24, 1986, hlm. 25-26).

10 Wignjosoebroto, Op. cit., hlm. 133, 137-38. 
Walau demikian konsep tentang hukum adat dan juga bagaimana ia diajarkan sebagai sebuah kajian ilmu hukum di Rechtshoogesschool tidak sama seperti apa yang dikembangkan oleh Van Vollenhoven. Adalah Ter Haar, yang merupakan murid dari Van Vollenhoven yang kemudian menjadi pengajar di Rechtshoogesschool yang bertanggung jawab membuat kajian hukum adat menjadi demikian. Berbeda dengan gurunya yakni Van Vollenhoven yang mengkonsepkan hukum adat sebagai suatu bentuk living law sebagaimana dikembangkan oleh Eugen Ehrlich, Ter Haar dengan "Teori Keputusan"-nya (beslissingenleer) mengembangkan hukum adat sebagai bagian dari hukum positif, yakni sebagai sumber hukum bagi para hakim dalam memutuskan perkara. ${ }^{11}$ Hal ini kemudian membuat kajian hukum adat sebagaimana dikembangkan oleh Ter Haar di Rechtshoogesschool menjadi sebuah bentuk kajian case law, di mana terdapat asumsi dasar bahwa dimungkinkan untuk menerapkan sebuah hukum yang telah ditetapkan dalam putusan hakim yang ada sebelumnya pada sebuah kasus yang baru, sebagaimana doktrin ini dikembangkan dalam tradisi common law. ${ }^{12}$ Berdasarkan pada fakta sebagaimana demikian, maka dapat dilihat konsep hukum adat dan pengajarannya seperti yang dilakukan oleh Ter Haar di Rechtshoogesschool, yakni sebagai sebuah bentuk kajian case law sebagai sumber dari hukum positif yang tentu saja berkarakter statis, sama sekali bukan merupakan bentuk living law yang memiliki karakter sebagai hukum yang akan terus berubah dan berkembang. Itulah mengapa hukum adat sebagai subyek pengajaran di fakultas hukum telah menjadi "hukum yang mati".

Jika beralih ke era pasca kolonial, kondisi yang ada sayangnya tidak jauh berbeda dengan apa yang terjadi sejak era Ter Haar. Hal ini dikarenakan disamping adanya fakta bahwa sejarah pendidikan hukum di Indonesia pada dasarnya adalah kelanjutan dari tradisi sebagaimana yang diperkenalkan oleh Rechtshoogesschool van Batavia, ${ }^{13}$ generasi awal sarjana hukum adat Indonesia seperti halnya Djojodigoeno dan Soepomo adalah alumni dari Rechtshoogesschool dan oleh karenanya konsep dan tradisi pengajaran hukum adat sebagaimana diperkenalkan oleh Ter Haar di atas diteruskan oleh mereka.${ }^{14}$ Situasi tersebut kemudian terus berlanjut hingga kini, yang membuat kurikulum hukum adat yang ada di hampir seluruh fakultas-fakultas hukum di Indonesia menjadi tidak begitu berbeda dengan kurikulum pada masa kolonial.

Kurangnya perkembangan di dalam kajian ilmu hukum adat atas adanya sebab seperti yang diuraikan di atas kemudian juga diperparah dengan pilihan kebijakan politik hukum yang diambil oleh negara Indonesia, yang pada gilirannya juga mempengaruhi perkembangan pendidikan hukum yang ada di fakultas-fakultas hukum di Indonesia. Jika pada masa Pemerintahan Kolonial Hindia Belanda diterapkan kebijakan pluralisme hukum seperti yang tertuang pada Pasal 131 jo. 163 Indsche Staatsregeling (IS), yang mengatur bahwa masyarakat pribumi dibiarkan untuk tetap tunduk pada hukum adatnya, negara Indonesia pada masa pasca kolonial justru menerapkan kebijakan yang sebaliknya, yakni kebijakan unifikasi hukum. ${ }^{15}$ Berdasarkan kebijakan unifikasi hukum ini, semua orang tunduk dan diatur oleh satu rezim sistem hukum yang sama, yakni hukum positif negara. Oleh karenanya negara melalui lembaga legislatif berangsur-angsur akan membuat hukum untuk setiap bidang kehidupan masyarakat. Hukum adat tetap dibiarkan hidup sebagai sumber hukum atas hal-hal yang belum diatur oleh hukum negara. Sebaliknya, begitu telah ada hukum negara yang

11 Benda-Beckmann, Op. cit., hlm. 187-188.

12 Ibid.

13 Mengenai sekilas tentang sejarah sekolah hukum pertama di Indonesia, dapat dilihat pada: Anonymous, "Sejarah dan Perkembangan Fakultas Hukum UI", http://law.ui.ac.id/v3/sejarah-dan-perkembangan/.

14 Benda-Beckmann, Op. cit., hlm. 188.

15 Pada awalnya, adalah juga menjadi rencana dari Pemerintah Kolonial Hindia Belanda untuk menerapkan kebijakan unifikasi hukum. Namun, rencana ini pada akhirnya gagal karena perlawanan yang gigih dari beberapa sarjana Belanda sendiri, dan salah satunya yang paling menonjol adalah Van Vollenhoven. Dapat dilihat pada Op. cit., Benda-Beckmann, 2009, adanya hlm. 192-194. 
mengatur suatu bidang, hukum adat harus dianggap tidak lagi efektif sebagai sebuah sumber hukum. Contoh dari hal ini bisa dilihat pada bidang hukum perkawinan dan hukum pertanahan. Sebelum ada perundang-undangan, sebagai bentuk hukum negara yang ada di Indonesia, yang mengatur soal perkawinan dan pertanahan, kedua bidang ini tunduk pada rezim hukum adat. Akan tetapi sejak tahun 1960 sebagai tahun diundangkannya UU No. 5/1960 tentang Pokok-Pokok Agria, dan sejak tahun 1974 sebagai tahun disahkannya UU No. 1/1974 tentang Perkawinan, urusan perkawinan dan pertanahan tidak lagi merujuk pada hukum adat karena sudah diatur secara unifikatif oleh kedua undang-undang tersebut. Mulai sejak saat itu, eksistensi hukum adat sebagai bagian sistem hukum nasional Indonesia dan juga sebagai bahan pengajaran di fakultas-fakultas hukum di Indonesia secara perlahan mengalami kematian, karena telah tergantikan oleh perundang-undangan.

2. "Bumi sebagai Ibu". Prinsip Dasar Hukum Adat tentang Tanah dan Landasan Pergerakan Masyarakat Adat dalam Memperjuangkan Hak Tenurial. Sebuah Contoh dari Komunitas Sedulur Sikep

Walaupun subjek hukum adat telah menjadi semacam "dead law" dan oleh karenanya membuat terjadinya stagnasi di dalam pengembangannya di fakultas-fakultas hukum, kehidupan dan perjuangan masyarakat adat di Indonesia khususnya dalam hal urusan tanah dan hak tenurial lainnya tidak sepenuhnya terdiskoneksi dari subyek kajian ini. Prinsip-prinsip hukum adat tentang tanah, sebagai salah satu topik dalam mata kuliah hukum adat, yang uniknya masih tetap diajarkan di fakultasfakultas hukum terlepas fakta bahwa telah ada UU No. 5 Tahun 1960, masih tetap dipegang teguh oleh sebagian, jika tidak sebagian besar, masyarakat adat di Indonesia terkait nilai-nilai tradisional mereka tentang tanah dan hak tenurial. Penulis menjumpai situasi ini dalam penelitian atas komunitas Sedulur Sikep di Desa Sukolilo, Kabupaten Pati, Propinsi Jawa Tengah.

Sedulur Sikep sendiri adalah sebuah komunitas tradisional yang pertama kali didirikan oleh seorang bernama Samin Surontiko di Blora, Jawa Tengah, pada tahun $1980 .{ }^{16}$ Komunitas ini kemudian berkembang dengan anggota yang hidup di sepanjang Pegunungan Kendeng yang terbentang mulai dari Kabupaten Kudus, Pati, Blora, dan Rembang di Jawa Tengah serta di Kabupaten Bojonegoro dan Ngawi di Jawa Timur.

Hal yang membuat komunitas tradisional ini unik adalah adanya fakta bahwa keanggotaan dari komunitas ini didasarkan pada keterikatan atas satu set nilai-nilai dan norma tradisional yang biasa disebut sebagai "ajaran samin", yang dipraktekkan dan dipertahankan oleh komunitas ini sejak masa ia didirikan hingga saat ini. ${ }^{17}$ Salah satu dari prinsip terpenting dalam ajaran samin adalah adanya larangan bagi anggota komunitas Sedulur Sikep untuk bekerja di lapangan pekerjaan selain sebagai petani. Alhasil semua anggota komunitas ini haruslah petani dan harus merupakan petani yang menggarap sawahnya sendiri (bukan buruh tani).

Terkait urusan tanah dan hak tenurial, ada sebuah ungkapan yang merefleksikan ajaran samin soal ini, yakni: "Lemah podho duwe, banyu podho duwe, kayu podho duwe" (tanah, air, dan hutan adalah milik bersama). ${ }^{18}$ Latar belakang mengapa penulis melakukan penelitian atas komunitas Sedulur Sikep adalah karena komunitas ini adalah komunitas yang paling aktif melakukan penolakan atas rencana pendirian industri semen di Pegunungan

16 Latar belakang historis dari komunitas ini bisa dibaca pada: H. J. Benda, \& Castles, L., "The Samin Movement", Brijdragen tot de Taal-, Land Volkenkunde, Volume 125, Nomor 2, 1969.

17 Benda \& Castles, Op. cit., hlm. 210. Menurut Van Vollenhoven Op. cit., Holleman, 1981, hlm. 45-53, sebagaimana juga dikutip oleh Op. cit., Benda-Beckmann 2009, hlm. 181, terdapat 4 (empat) jenis model persekutuan masyarakat (hukum) adat di Indonesia, yakni: 1. Persekutuan yang didasarkan pada ikatan genealogis, 2. Persekutuan yang didasarkan pada ikatan teritori (wilayah), 3. Persekutuan yang didasarkan pada gabungan ikatan genealogis dan teritori, 4. Persekutuan yang terbentuk atas ikatan yang sifatnya sukarela (voluntary corporate association). Komunitas tradisional Sedulur Sikep dapat dikategorikan termasuk ke dalam jenis persekutuan masyarakat (hukum) adat yang ke-4

18 Benda \& Castles, Op.cit., hlm. 223. 
Kendeng. ${ }^{19}$ Berdasarkan hasil penelitian tersebut atas komunitas ini di Desa Sukolilo, paling tidak terdapat dua prinsip fundamental yang menjadi latar belakang perlawanan komunitas Sedulur Sikep terhadap rencana pendirian industri semen. ${ }^{20}$

Prinsip yang pertama adalah adanya ajaran samin yang mewajibkan anggota komunitas Sedulur Sikep untuk hanya menekuni pekerjaan sebagai petani. Dikarenakan aktivitas bertani di Pegunungan Kendeng sangatlah bergantung pada sumber air yang ada di pegunungan ini, maka komunitas ini melihat aktivitas industri semen khususnya penambangan batu kapur dari pegunungan ini sebagai ancaman atas suplai air dari Pegunungan Kendeng pada khususnya dan kelestarian ekologis Pegunungan Kendeng pada umumnya. Ujungnya hal ini akan mengancam tradisi pertanian dari komunitas ini serta masyarakat petani lainnya di wilayah Kendeng.

Prinsip kedua dan sekaligus yang terpenting adalah adanya nilai yang memaknai tanah dan/atau bumi sebagai "ibu", yang mana nilai ini mendorong komunitas Sedulur Sikep untuk melakukan penolakan terhadap industri semen atas alasan perlindungan terhadap lingkungan. Sebagaimana yang dijelaskan kepada penulis oleh Gunretno, salah satu pemuka dari komunitas Sedulur Sikep di Desa Sukolilo, komunitasnya memaknai kata "bumi" sebagai kependekan dari kata "ibu-mami", yakni ibu yang telah menjadi tempat lahir dari segala makhluk yang hidup di atasnya dan oleh karenanya semua makhluk ini sebagai anak-anak dari "ibu-bumi" secara niscaya menggantungkan hidup mereka atasnya. ${ }^{21}$ Gunretno menjelaskan lebih lanjut bahwa sebagai karakteristik yang umum dimiliki oleh seorang ibu, tanah atau bumi akan selalu memberikan hal yang tebaik bagi "anakanaknya", yakni semua makhluk yang hidup di atasnya, dan sebagai "seorang ibu" yang senantiasa memberi makan "anak-anaknya", tanah/bumi senantiasa akan menyediakan sumber penghidupan dan makanan bagi manusia dan makhluk hidup lainnya. Oleh karena itu, sebagai bentuk tanggung jawab dari "anak-anak ibu-bumi", manusia berkewajiban untuk senantiasa menghormati dan melindungi tanah/bumi dan mencegah terjadinya segala macam aktivitas yang sifatnya dapat membawa kerusakan dan kehancuran seperti halnya aktivitas penambangan untuk industri semen. ${ }^{22}$

Penjelasan sebagaimana diberikan oleh Gunretno di atas menunjukkan gambaran yang jelas mengapa komunitas Sedulur Sikep begitu persisten dalam melakukan penolakan terhadap pendirian industri semen. Mereka melihat pendirian industri semen ini sebagai ancaman yang serius terhadap "keselamatan ibu/bumi" mereka, yakni berupa ancaman kerusakan ekologis, dan oleh karena itu sebagai "anak-anak ibu-bumi" mereka merasa berkewajiban untuk melakukan penolakan terhadap pedirian industri semen ini.

Kembali kepada soal kajian ilmu hukum adat, gagasan tentang tanah/bumi sebagai "ibu" merupakan salah satu prinsip dasar hukum adat soal tanah. Sebagaimana dijelaskan oleh Moh. Koesnoe, terdapat sebuah mitologi yang menyimbolkan prinsip dasar hukum adat soal tanah, yakni ide bahwa semua makhluk hidup dan manusia yang hidup di atas bumi adalah "anak-anak" dari hasil "perkawinan" antara langit sebagai "bapak" dan bumi sebagai "ibu". ${ }^{23}$ Oleh karena itu, berdasarkan pandangan filosofis sebagaimana demikian, terdapat sebuah hubungan metafisis yang kuat antara manusia dengan tanah dan lingkungan di mana ia hidup dan tinggal, sebagaimana hubungan yang kuat antara seorang anak dengan ibunya dan dengan saudara-saudara kandungnya, dan hubungan yang intim sebagaimana demikian niscaya juga membawa adanya tanggung jawab untuk senantiasa

19 Hasil dari penelitian ini bisa dibaca pada: Kurniawan, Joeni Arianto "Contested Land, Contesting Laws. A Context of Legal Pluralism and Industrialization in Indonesia", Sortuz; Oñati Journal of Emergent Socio-Legal Studies, Volume 6, Issue 2, $2014 .$, hlm. 93 -106.

20 Kurniawan, Op.cit., hlm. 100.

21 Ibid.

22 Ibid.

23 M. Koesnoe, 2000, Prinsip-Prinsip Hukum Adat tentang Tanah, Ubhara Press, Surabaya, hlm. 6. 
menyayangi, menolong, dan melindungi satu sama lain. ${ }^{24}$ Itulah mengapa, sebagai "anak-anak dari ibu bumi”, manusia yang hidup di atas bumi bertanggung jawab untuk membela dan menjaga perlindungan kelestarian dan kesejahteraan tanah dan lingkungan di mana ia berada, seperti tanggung jawab seorang anak untuk senantiasa menjaga dan melindungi keselamatan ibu dan seluruh keluarganya. ${ }^{25} \mathrm{Hal}$ inilah yang juga kemudian menjadi alasan mengapa menurut hukum adat tidak boleh terjadi adanya tindakan yang sifatnya dapat merusak tanah dan lingkungan sekitarnya.

Lebih jauh lagi, berdasarkan pandangan filosofis sebagaimana di atas, tanah dengan segala macam sumber daya yang ada di dalamnya menurut hukum adat tidak dimaknai sebagai benda material semata yang bisa dikuasai dan dimiliki secara individual dan bahkan dieksploitasi. Alihalih, tanah beserta segala sumber daya alamnya hanya bisa dinikmati secara bersama seiring dengan tanggung jawab yang diberikan oleh alam untuk senantiasa menjaga dan melindungi kelestariannya. ${ }^{26}$ Oleh karena itu, menurut hukum adat, tanah merupakan aset komunal yang dikuasai oleh sebuah kesatuan masyarakat adat secara kolektif, yang mana penguasaan kolektif atas wilayah tanah sebagaimana demikian dinamakan sebagai "(hak) ulayat". ${ }^{27}$ Adanya nilai soal hak ulayat sebagai penguasaan bersama atas tanah ini kemudian menentukan lebih lanjut soal pengaturan hukum adat tentang kepemilikan tanah. Dengan adanya hak ulayat, maka tanah dalam tingkatan tertinggi berada di bawah kekuasaan kesatuan masyarakat adat yang hidup dan tinggal di wilayah tanah tersebut. Oleh karena itu wilayah tanah ini menjadi bersifat terlarang bagi siapa saja yang bukan anggota kesatuan masyarakat adat yang bersangkutan. ${ }^{28}$ Oleh karena itu, berdasarkan pengaturan sebagaimana demikian, mereka yang dapat menggunakan tanah dan menikmati segala hasil sumber daya alamnya adalah terbatas pada anggota kesatuan masyarakat adat yang memiliki hak ulayat atas tanah tersebut, dan oleh karenanya hak untuk penggunaan tanah tersebut hanya bisa diberikan kepada anggota komunitas masyarakat adat tersebut saja. Itulah mengapa, menurut hukum adat, menjual tanah kepada orang di luar komunitas masyarakat adat yang memiliki ulayat atas tanah tersebut adalah dilarang, sebab hal ini didasarkan pada prinsip bahwa eksistensi hak ulayat senantiasa melekat pada kesatuan masyarakat adat yang berada di wilayah tanah tersebut, dan otoritas hak ulayat tersebut tidak bisa dialihkan kepada pihak lain. ${ }^{29}$ Pengaturan sebagaimana demikian sesuai dengan pandangan soal hubungan yang sifatnya abadi antara ibu dan anaknya yang tidak akan bisa diintervensi oleh pihak lain.

Merujuk kepada semua penjabaran di atas, jelas terlihat bahwa apa yang menjadi panduan dan sekaligus pendorong bagi komunitas Sedulur Sikep di Desa Sukolilo dalam melakukan penolakan atas pendirian industri semen adalah hukum adat yang mengatur mereka sebagai sebuah komunitas tradisional yang masih senantiasa mempertahankan nilai-nilai adat yang mereka miliki (ajaran samin).

\section{Penutup}

Berdasarkan semua penjabaran di atas, setidaknya terdapat dua kesimpulan yang bisa diambil. Pertama, secara umum, kajian ilmu hukum adat yang diajarkan di fakultas-fakultas hukum di Indonesia dapat dimaknai sebagai sebuah "dead law" atau "kajian hukum yang telah mati". Hal ini dikarenakan konseptualisasi kajian hukum adat yang lebih mengarah kepada studi case law alih-alih berupa kajian living law yang hidup di dalam tatanan internal dari sebuah kesatuan/ komunitas masyarakat adat. Dikarenakan adanya

27 Ibid., hlm. 22. I. Sudiyat, 1981, Hukum Adat Sketsa Asas, Liberty, Yogyakarta, hlm. 2. Wignjodipuro, Op.cit., hlm. 248.

28 Koesnoe, Op.cit., hlm. 39. S. Wignjodipuro, 1979, Pengantar dan Asas-Asas Hukum Adat, Alumni, Bandung, hlm. 250.

29 Wignjodipuro, Op.cit. hlm. 250. 
stagnasi sebagaimana demikian, kajian hukum adat cenderung menjadi kurang kontributif terhadap dinamika masyarakat adat yang terjadi dewasa ini, termasuk dalam hal perjuangan atas pengakuan dan perlindungan atas hak-hak mereka. Sementara itu, sebagai poin kesimpulan yang kedua, sesungguhnya masih terdapat relevansi dan signifikasi antara beberapa prinsip-prinsip hukum adat dengan kehidupan masyarakat adat saat ini, seperti halnya relevansi hukum adat tentang tanah, lingkungan, dan hak tenurial yang dimiliki oleh masyarakat adat sebagaimana ditunjukkan oleh contoh atas kasus yang terjadi pada komunitas Sedulur Sikep di Kebupaten Pati di Jawa Tengah.

Oleh karena itu, untuk membuat agar terjadi keterhubungan yang lebih baik dan lebih signifikan antara studi hukum adat dan kehidupan masyarakat adat, setidaknya terdapat beberapa hal yang perlu dilakukan.

Pertama, merekonseptualisasi kajian hukum adat menjadi suatu kajian living law, yakni sebagai hukum yang senyatanya hidup dan eksis di dalam kesatuan-kesatuan masyarakat adat, sesuai dengan konsep yang dikembangkan oleh Eugen Ehrlich. Oleh karena itu, perhatian para sarjana dalam mempelajari dan mengembangkan subjek kajian ini tidak boleh lagi tertuju pada putusan-putusan hakim (yang mengambil sumber pada hukum adat) seperti yang dikembangkan oleh Ter Haar, tetapi kepada kehidupan masyarakat adat itu sendiri sebagai wadah dan sekaligus sumber eksistensi hukum adat yang hidup di lingkungan mereka.

Walau demikian hal di atas tidak akan bisa dilakukan jika kesadaran para yuris dan fungsionaris hukum (pemerintah, hakim, jaksa, dll.) masih didominasi oleh paradigma sentralisme/positivisme hukum yang memaknai hukum negara sebagai segala-galanya. Mengembalikan konsep hukum adat sebagai suatu living law tidak akan berujung pada reposisi hukum adat sebagai salah satu elemen penting dalam sistem hukum di Indonesia jika para yuris dan fungsionaris hukum yang ada masih memeluk erat gagasan lama bahwa hanya hukum negara (perundang-undangan) yang merupakan satu-satunya jenis hukum yang efektif dalam sebuah sistem hukum yang ada yang mengatasi jenis hukum yang lain.

Oleh karena itu terdapat hal kedua yang perlu dilakukan, yakni dekonstruksi atas paradigma sentralisme/positivisme hukum dengan memberikan pendidikan dan pemahaman kepada para calon yuris dan fungsionaris hukum mengenai "keniscayaan pluralisme hukum". Diskursus soal pluralisme hukum di sini tidak hanya sebatas sebagai sarana pembantu bagi para sarjana hukum agar memiliki perhatian dan kesadaran bahwa ada banyak jenis-jenis hukum di luar hukum negara. Melainkan juga untuk berperan sebagai paradigma yang menuntun para aktor agar memiliki perhatian terhadap jenis-jenis hukum di luar hukum negara dan terlebih untuk membawa jenis-jenis hukum di luar hukum negara tersebut ke dalam analisis yang mereka lakukan dalam rangka membuat sebuah putusan hukum atau sebuah kebijakan. Melalui paradigma sebagaimana demikian, hukum negara tidak lagi memainkan monopoli di dalam sistem hukum yang ada. Melainkan hanya akan berperan sebagai salah satu elemen sistem hukum yang berkoeksistensi dengan hukum-hukum adat dan jenis-jenis living law lainnya, serta dengan kaidah hukum alam (moralitas) dan kaidah hukum internasional, termasuk HAM. ${ }^{30}$ Dengan diambilnya hukum adat dari kesatuan-kesatuan masyarakat adat sebagai bagian dari bahan analisis dan pengambilan keputusan oleh para fungsionaris hukum, maka dengan sendirinya hak-hak dari masyarakat adat

30 Mengenai jenis kajian pluralisme hukum sebagaimana demikian, salah satunya bisa dirujuk pada teori Kite Model of Legal Pluralism yang dikembangkan oleh Werner Menski (2006) (2008) (2014). Dapat dilihat di Menski, W., 2006, Comparative Law in Global Context, Cambridge University Press, Cambridge., Menski, W., 2008, Accommodating Religious Needs in Relation to Marriage: Flying Kites and Navigating State Law and Other Forms of Law, Facolta di Giurisprudenza, Universita degli Studi dell'Insubria, Como., dan Menski, W., 2014, Remembering and Applying Legal Pluralism: Law as Kite Flying. In S. P. Donland, \& L. H. Urscheler, Concept of Law. Comparative, Jurisprudential, and Social Science Perspective, Routledge, London and New York, hlm. 117-136. 
yang bersangkutan juga akan terperhatikan dengan serius.

Berangkat dari sini terlihat bahwa sekali lagi, hal ini menjadi tanggung jawab dari para akademisi di dalam proses pendidikan hukum untuk menyebarluaskan paradigma pluralisme hukum kepada para mahasiswa hukum sebagai calon fungsionaris-fungsionaris hukum.

\section{DAFTAR PUSTAKA}

\section{A. Buku}

Holleman, J, 1981, Van Vollenhoven on Indonesian Adat Law, Martinus Nijhoff, The Hague.

Koesnoe, M., 2000, Prinsip-Prinsip Hukum Adat tentang Tanah, Ubhara Press, Surabaya.

Menski, W., 2006, Comparative Law in Global Context, Cambridge University Press, Cambridge.

Menski, W., 2008, Accommodating Religious Needs in Relation to Marriage: Flying Kites and Navigating State Law and Other Forms of Law, Facolta di Giurisprudenza, Universita degli Studi dell'Insubria, Como.

Menski, W., 2014, Remembering and Applying Legal Pluralism: Law as Kite Flying. In S. P. Donland, \& L. H. Urscheler, Concept of Law. Comparative, Jurisprudential, and Social Science Perspective, Routledge, London and New York. hlm. 117-136

Simarmata, R. (2006). Pengakuan Hukum terhadap Masyarakat Adat di Indonesia. Jakarta: UNDP.

Sudiyat, I., 1981, Hukum Adat Sketsa Asas, Liberty, Yogyakarta.

Wignjodipuro, S., 1979, Pengantar dan Asas-Asas Hukum Adat, Alumni, Bandung.

\section{B. Jurnal}

Wignjosoebroto, S, 1994, Dari Hukum Kolonial ke Hukum Nasional, Radja Grafindo Persada, Jakarta.

Benda, H. J., \& Castles, L., "The Samin Movement", Brijdragen tot de Taal-, Land Volkenkunde, Volume 125, Nomor 2, 1969.

Benda-Beckmann, F. a. , "The Social Life of Living law in Indonesia", In M. Hertogh, 2009, Living Law. Reconsidering Eugen Ehrlich,
Hart Publishing, Oxford and Portland Oregon.

Griffits, J., What is Legal Pluralism, Journal of Legal Pluralism and Unofficial Law, Number 24, 1986.

Hertogh, M. , "From 'Men of Files' to 'Men of the Senses': A Brief Characterisation of Eugen Ehrlich's Sociology of Law", In M. Hertogh, 2009, Living Law. Reconsidering Eugen Ehrlich, Hart Publishing, Oxford and Portland Oregon.

\section{Internet}

Kurniawan, J. A., "Contested Land, Contesting Laws. A Context of Legal Pluralism and Industrialization in Indonesia", Sortuz; Oñati Journal of Emergent Socio-Legal Studies, Volume 6, Issue 2, 2014.

Humas Sekretariat Kabinet Republik Indonesia, "Serahkan 9 Surat Pengakuan Hutan Adat, Presiden Jokowi: Pertahankan Fungsi Konservasi, Jangan Diperjualbelikan", http:// setkab.go.id/serahkan-9-surat-pengakuanhutan-adat-presiden-jokowi-pertahankanfungsi-konservasi-jangan-diperjualbelikan/.

Fakultas Hukum Universitas Indonesia, "Sejarah dan Perkembangan Fakultas Hukum UI”, http:// law.ui.ac.id/v3/sejarah-dan-perkembangan/.

\section{Putusan Pengadilan}

Putusan Mahkamah Konstitusi Nomor 31/ PUU-V/2007 perihal Pengujian UndangUndang Nomor 31 Tahun 2007 tentang Pembentukan Kota Tual di Propinsi Maluku terhadap Undang-Undang Dasar Negara Republik Indonesia Tahun 1945, 18 Juni 2008. 